\title{
Analysis of Renewable Energy Utilization Potential in Buildings of China
}

\author{
Min-hua Cai, Lan Tang* \\ Guangdong Provincial Key Laboratory of Building Energy Efficiency and Application Technologies, \\ Guangzhou University, Guangzhou, China \\ Email: 316543111@qq.com, tanglan@gzhu.edu.cn
}

Received February, 2013

\begin{abstract}
As a country of great population, China has increasing building energy consumption continuously. It not only threatens the lack of total energy but also hardens the progress of protecting environment. Therefore, it forces the country to accelerate finding substitution application of conventional energy in building, renewable energy building utilization. In base of 2010, this study explores the potential of the renewable energy building utilization by using energy consumption analysis until 2030 and predicts annual alternative quantity of renewable energy in different situations.
\end{abstract}

Keywords: Renewable Energy; Building Energy Consumption; Potential Analysis; Scenario Analysis Method

\section{Introduction}

Balancing every influence factors plays an important role in national prosperity and sustainable development, so energy balance has been a long-term and urgent task. The three global traditional energy, oil, coal and natural gas, accounted for more than $90 \%$ of the energy consumption. Implementing the scheme of traditional energy reduction is so necessary. Although our country is a rich coal country, because of the large population and causes personal average energy quantity is lower than the world average energy quantity. According to the analysis of journal academic paper "Thinking about the Problems of Chinese Energy", published in "Journal of Shanghai Jiaotong University" .China's average coal quantity is only $32.8 \%$ of the world's average coal quantity, demonstrating clearly our national energy tension.

Moreover, with the improvement of social life quality, China's building terminal energy consumption has accounted for nearly $27.6 \%$ of the total primary energy consumption. "2012 Annual Report on China Building Energy Efficiency" [1] issued that personal building energy consumption of China's urban people is only onefifth of the total building energy consumption, However, due to the large population base, the total building energy consumption quantity is very large.

In the face of such serious situation, the state has adopted a series of measures:

On the one hand, main mandatory measures adopted by the national building field are as follow:

1) Strictly controlling the size of the general public buildings and the growth of building energy consumption;

2) Advocating saving the energy consumption model and way of life;

3) Establishing the supervision system of building energy efficiency;

4). Ensuring the smooth implementation of building energy efficiency;

5) Strengthening the incentive policy and giving priority to financial subsidies.

On the other hand, there is a large-scale application of renewable energy replacing conventional fossil energy. At the same time, people's consciousness of energy conservation and emission reduction has been improved. With the global appeal of "low-carbon development", so it's the tendency to limit fossil energy consumption and implement clean or renewable energy consumption nowadays. Utilization of renewable energy in building field has a great large of potential.

\section{Forecast Analysis of Energy Saving Potential of the Renewable Energy Utilization in Building}

\subsection{Situation Forecast of Building Energy Consumption (2010-2030)}

According to "2008 Annual Report on China Building Energy Efficiency" [2], we can organize the specific data of building energy consumption from 2002 to 2010 as following Table 1 [3]. Taking the statistics data into account, the average annual growth rate from 2002 to 2010 
comes out to be $12.64 \%$.This is the reality state of building energy consumption growth recently.

According to Chinese long-term planning of energy [4], the total energy consumption should be controlled bellow 4.2 billion tce until 2020, with 20\% 25\% occupied by building energy consumption. So the average annual growth rate of building energy consumption from 2010 to 2030 can come out to be $0.9 \%$, while assuming 1 billion tce in 2020. This is the ideal state of building energy consumption growth.

During 2010 to 2030, with the development of the social mechanism and social progress, the state begins to pay more and more attention to building energy saving and introduces some corresponding laws or regulations. It improves the construction equipment efficiency by means of the improved science and technology. The society has formed a mature saving energy consumption lifestyle and so on .These lowers average annual growth rate. Taking a comprehensive consideration of the influence, we can set an average annual growth rate of $4.00 \%$ and forecast the development of building energy consumption from 2010 to 2030 (as Table 2)

\subsection{The Alternative Quantity of Renewable Energy in Building Energy Consumption (2010-2030) (Baseline Scenario)}

According to the published alternative quantity of renewable energy in 2010 and the index achieved by "the Medium and Long-term Development Plan of Renewable Energy" [4] until 2020, we can calculate the alternative quantity growth trend of renewable energy in building energy consumption and predict alternative data of 2010 to 2030 .

By the end of 2010 [5] , the installation of solar energy water heater amounts to 168 million square meters and its alternative fossil energy is about 20 million tons of standard coal; Roof photovoltaic power generation project is up to 4.4 billion kilowatt hour, which reduces 1.42 million tons of standard coal; Ground source heat

Table 1. The development of building energy consumption from 2002 to 2010 (unit: ten thousand tce).

\begin{tabular}{|c|c|c|c|c|c|}
\hline Year & 2002 & 2004 & 2006 & 2008 & 2010 \\
\hline North town heating & 8584 & 12925 & 16205 & 17985 & 16330 \\
\hline $\begin{array}{l}\text { Residential (except } \\
\text { the northern heating) }\end{array}$ & 11228 & 12787 & 14623 & 16290 & 47910 \\
\hline $\begin{array}{l}\text { Public buildings } \\
\text { (except the northern } \\
\text { heating) }\end{array}$ & 12229 & 26018 & 18716 & 30595 & 17370 \\
\hline total & 32041 & 51730 & 49544 & 64870 & 83620 \\
\hline $\begin{array}{l}\text { annual rate of } \\
\text { growth (\%) }\end{array}$ & 6.29 & 35.32 & 8.77 & 16.90 & 14.23 \\
\hline
\end{tabular}

pump can save 4.6 million tons of standard coal; Methane is about 14 billion cubic meters and its alternative energy is 11.14 million tons of standard coal. The total alternative quantity is about 37.16 million tons of standard coal (shown as Table 3), accounting for $4.44 \%$ of building energy consumption.

In 2010, the solar energy water heater area is 168 million square meters and planning area of 2020 [5] is 800 million square meters. Refer to the growth speed of renewable energy production from 2010 to 2020, the average annual growth rate comes out to be $16.89 \%$. Therefore we can predict the alternative quantity of solar energy

Table 2. The prediction of building energy consumption from 2010 to 2030.

\begin{tabular}{ccccc}
\hline Year & $\begin{array}{c}\text { Population } \\
\text { (hundred } \\
\text { million) }\end{array}$ & $\begin{array}{c}\text { Building area } \\
\text { (hundred } \\
\text { Million } \mathrm{m}^{2} \text { ) }\end{array}$ & $\begin{array}{c}\text { Building energy } \\
\text { consumption } \\
\text { (hundred } \\
\text { million tce) }\end{array}$ & $\begin{array}{c}\text { Personal building } \\
\text { energy consumption } \\
\text { (kgce/per) }\end{array}$ \\
\hline 2010 & 13.40 & 453 & 8.36 & 623.88 \\
2015 & 13.70 & 513.17 & 10.17 & 742.57 \\
2020 & 14.00 & 569.36 & 18.32 & 1308.28 \\
2030 & 14.50 & 632.05 & 27.11 & 1870.08 \\
\hline
\end{tabular}

Table 3. the alternative quantity prediction of renewable energy in building energy consumption from 2010 to 2030 (converted into ten thousand tce/year).

\begin{tabular}{|c|c|c|c|c|c|}
\hline year & & 2010 & 2015 & 2020 & 2030 \\
\hline \multirow[b]{2}{*}{$\begin{array}{l}\text { Solar water } \\
\text { heater }\end{array}$} & ten thousand $\mathrm{m}^{2}$ & 16800 & 34661 & 80000 & 230000 \\
\hline & $\begin{array}{l}\text { ten thousand } \\
\text { tce/year }\end{array}$ & 2000 & 3943 & 9100 & 26163 \\
\hline \multirow{2}{*}{$\begin{array}{l}\text { Roof photovoltai } \\
\text { power } \\
\text { generation }\end{array}$} & $\begin{array}{l}\text { hundred million } \\
\mathrm{kW} \cdot \mathrm{h}\end{array}$ & 44 & 62 & 188 & 804 \\
\hline & $\begin{array}{l}\text { ten thousand } \\
\text { tce/year }\end{array}$ & 142 & 201 & 608 & 2605 \\
\hline $\begin{array}{l}\text { Shallow } \\
\text { Geothermal } \\
\text { energy }\end{array}$ & $\begin{array}{l}\text { ten thousand } \\
\text { tce/year }\end{array}$ & 460 & 1000 & 2200 & 10522 \\
\hline \multirow{2}{*}{ Methane } & $\begin{array}{l}\text { hundred million } \\
\mathrm{m}^{3}\end{array}$ & 140 & 200 & 440 & 1383 \\
\hline & $\begin{array}{l}\text { ten thousand } \\
\text { tce/year }\end{array}$ & 1114 & 1591 & 3500 & 11000 \\
\hline Total & $\begin{array}{l}\text { ten thousand } \\
\text { tce/year }\end{array}$ & 3716 & 6735 & 15408 & 50289 \\
\hline $\begin{array}{l}\text { Proportion in } \\
\text { building energy } \\
\text { consumption }\end{array}$ & $\%$ & 4.44 & 6.62 & 10.06 & 22.18 \\
\hline
\end{tabular}


Table 4. Prediction of renewable energy in building energy consumption under different situations from 2010 to 2030 (converted into ten thousand tce/year).

\begin{tabular}{|c|c|c|c|c|c|}
\hline $\mathrm{N}$ & year & 2010 & 2015 & 2020 & 2030 \\
\hline \multirow{2}{*}{1} & baseline scenario & 3716 & 6735 & 15408 & 50289 \\
\hline & Proportion (\%) & 4.44 & 6.62 & 10.06 & 22.18 \\
\hline \multirow{2}{*}{2} & People know deeply & 3901 & 7071 & 16179 & 52804 \\
\hline & Proportion（\%） & 4.67 & 6.95 & 10.56 & 23.29 \\
\hline \multirow{2}{*}{3} & Well-established policy & 4087 & 7408 & 16949 & 55318 \\
\hline & Proportion（\%） & 4.89 & 7.28 & 11.06 & 24.40 \\
\hline \multirow{2}{*}{4} & Mature technology & 4087 & 7408 & 16949 & 55318 \\
\hline & Proportion (\%) & 4.89 & 7.28 & 11.06 & 24.40 \\
\hline \multirow{2}{*}{5} & $\begin{array}{l}\text { People know deeply + } \\
\text { Well-established policy }\end{array}$ & 4273 & 7745 & 17719 & 57832 \\
\hline & Proportion（\%） & 5.11 & 7.61 & 11.57 & 25.51 \\
\hline \multirow{2}{*}{6} & $\begin{array}{l}\text { People know deeply+Mature } \\
\text { technology }\end{array}$ & 4273 & 7745 & 17719 & 57832 \\
\hline & Proportion（\%） & 5.11 & 7.61 & 11.57 & 25.51 \\
\hline $\mathrm{N}$ & year & 2010 & 2015 & 2020 & 2030 \\
\hline \multirow{2}{*}{7} & $\begin{array}{l}\text { Well-establish-ed policy + } \\
\text { Mature technology }\end{array}$ & 4459 & 8081 & 18490 & 60347 \\
\hline & Proportion (\%) & 5.33 & 7.95 & 12.07 & 26.61 \\
\hline \multirow{2}{*}{8} & Best scene & 4645 & 8418 & 19260 & 62861 \\
\hline & Proportion（\%） & 5.56 & 8.28 & 12.57 & 27.72 \\
\hline
\end{tabular}

Proportion: the proportion of renewable energy consumption in total building energy consumption.

water heater in 2015 and 2030. According to the same calculation methods, the alternative quantity of roof photovoltaic power generation, shallow geothermal energy and methane can be respectively predicted from 2010 to 2030 and the related data converted into unity unit: ten thousand tce/year, shown in Table 3. Until 2030, renewable energy in building applications can save 502.89 million tce and is 13.5 times that of 2010 , accounting for $22.18 \%$ of the total energy consumption. It can ease the shortage of conventional energy sources which can be used in any other field.

\subsection{The Alternative Quantity of Renewable Energy in Building Energy Consumption under Different Situations (2010-2030)}

In the situational analysis, because of the popular utilization technology of the renewable energy in building, we can assume 5\% of increase rate. Moreover, due to the standard system and incentive policy improvement, it makes the alternative quantity increased by $10 \%$. Besides, it will be increased by $10 \%$ due to the mature utilization technology of renewable energy. In these ways, this research explores the alternative quantity of renewable energy in building under various situations (shown as Table 4).

When it comes to be the best scene, which means people know deeply, standard system and incentive policy of renewable energy construction become more perfect and utilization technology of renewable energy is mature, the alternative quantity is up to 628.61 million tce, accounting for $27.72 \%$ of building energy consumption. It's 125.72 million tce more than baseline scenario.

\section{Conclusions}

Based on 2010, this study explores the potential of renewable energy development in building energy consumption in 2030 and uses scenario analysis method to predict the alternative quantity of renewable energy in different situations. So the relevant departments led to realizing energy saving direction and key areas of renewable energy in the future. It will be bound to improve the building integration technology and perfect building design specifications.

\section{Acknowledgements}

We thank the support from the National Natural Science Foundation of China (51078092), "Yangcheng scholar" project of Education Bureau of Guangzhou (10A039G) and Guangzhou city-belonged university research project of Education Bureau of Guangzhou (10A020).

\section{REFERENCES}

[1] Qinghua University Building Energy Research Center, 2012 Annual Report on China Building Energy Efficiency, 2012.

[2] Qinghua University Building Energy Research Center, 2008 Annual Report on China Building Energy Efficiency, 2008

[3] National Bureau of Statistics of the People's Republic of China, 2001-2011China Statistical Yearbook, 2001-2011.

[4] National Development and Reform Commission of the People's Republic of China, Medium and Long-term Development Plan of Renewable Energy of the People's Republic of China, 2007.

[5] National Energy Bureau of the People's Republic of China, Renewable Energy Development 1025 planning, 2012. 